\title{
Rancang Bangun Mesin Pemipil dan Penghancur Tongkol Jagung
}

\section{Design of Corn Sheller And Corncob Crusher Machine}

\author{
E. Prabowo, F. Agil Renaldy, F. Indra Kusuma, Winarto, Zainal Arifin \\ Jurusan Teknologi Pertanian, Politeknik Negeri Lampung \\ Jl. Soekarno-Hatta no. 10 Rajabasa-Bandar Lampung 35144
}

\begin{abstract}
Corn is one of the important plants for human life, especially in Indonesia. This is because corn is the second food crop commodity after rice. In Indonesia, there are still many post-harvest maize product processing using the traditional method by peeling corn by hand, so that the yield of corn production is not comparable with the labor for processing the corn harvest. Agricultural statistics show that maize production in Indonesia has always increased from year to year. In order to better support the conversion process of corn cobs waste into animal feed, a chopper is needed. The machine functions to chop the corn cobs so that they are easier for livestock to consume as well as accelerate the work of bacteria during the fermentation process. If the two processes are carried out on separate machines, it will take a long time to complete. This study aims to make a machine that combines a corn sheller machine with a corn cobs crusher. The results of testing the corncob crusher and shelling machine gave 10 $\mathrm{kg} / \mathrm{hour}$ shelling capacity, $13 \%$ unshipped corn, 68.9\% corn shelling yield, $15 \mathrm{~kg} / \mathrm{hour}$ corn cobs crushing machine capacity, $85.28 \%$ yield of corn cobs crushing.
\end{abstract}

Key words: design, corn shelling machine, corn cobs crusher

Naskah ini diterima pada tanggal 2 Nopember 2020, direvisi pada tanggal 16 Nopember 2020 dan disetujui untuk diterbitkan pada tanggal 15 Desember 2020

\section{PENDAHULUAN}

Jagung merupakan salah satu tanaman yang penting bagi kehidupan manusia khususnya di Indonesia. Hal ini dikarenakan jagung adalah komoditi tanaman pangan kedua setelah padi. Berdasarkan hitungan Direktorat Jendral Tanaman Pangan (TP) Kementan, produksi jagung dalam 5 tahun terakhir meningkat rata-rata 12,49\% per tahun. Itu artinya tahun 2018 produksi jagung diperkirakan mencapai 30 juta ton pipilan kering (Dirjen Tanaman Pangan 2018). Hal ini juga didukung oleh data luas panen per tahun yang meningkat $11,06 \%$, dan produktivitas rata rata meningkat $1,42 \%$ (ARAM I, BPS 2018).

Melihat peningkatan produksi jagung yang meningkat dari tahun ke tahun di Indonesia, maka pemanfaatan tanaman jagung memiliki potensi untuk dikembangkan lagi. Penggunaan tanaman jagung di Indonesia semakin meningkat, karena perannya sebagai bahan pangan yang mengandung karbohidrat dan protein yang cukup tinggi.Disamping itu juga bagian-bagian 
seperti bulir, tongkol, batang dan daun dari tanaman jagung itu juga dapat dimanfaatkan untuk bahan pakan ternak, kayu bakar, pupuk kompos, bahan baku industri dan rumah tangga (ARAM I, BPS 2018). Pemanfaatan jagung di Indonesia sebagian besar hanya sebatas bahan makanan yang diolah lalu dikonsumsi secara langsung begitu saja. Padahal, apabila kita menerapkan teknologi pada proses pengolahan jagung itu sendiri, hal ini dapat meningkatkan nilai komoditi jagung itu sendiri dengan menjadikan jagung menjadi berbagai produk pangan seperti pati jagung, bubur jagung, mie jagung, susu jagung dan tepung jagung. Hal ini dikarenakan jagung mengandung Karbohidrat, Protein, Lemak, Serat, Kalsium, Fosfor, Vitamin A,C,B1,B2 yang baik untuk kesehatan (Yuliyana, 2014).

Tanaman jagung juga dapat digunakan sebagai bahan pakan untuk ternak, tentunya dengan melewati beberapa proses terdahulu sebelum diberikan kepada hewan ternak, karena pada tongkol jagung banyak mengandung nutrisi meliputi kadar air, bahan kering, protein kasar dan serat yang baik untuk pertumbuhan hewan ternak. Kendala yang dialami pada saat pengolahan jagung ini adalah pada proses pemipilan biji jagung, karena untuk melanjutkan pada tahap pengolahan jagung berikutnya, tongkol jagung harus terpisah dengan bijinya terlebih dahulu agar lebih mudah mengolah dan mendapatkan tepung jagungnya (Anonim, 2019).

Di Indonesia pengolahan hasil pasca panen jagung masih banyak yang menggunakan cara tradisional dengan cara memipil jagung menggunakan tangan,sehingga tidak sebanding antara hasil produksi jagung dengan tenaga kerja untuk memproses hasil panen jagung. Untuk itu dibutuhkan mesin pemipil jagung yang dapat mengolah hasil panen jagung secara efisien. Mesin pemipil jagung merupakan sebuah mesin yang digunakan untuk memisahkan biji jagung dari tongkolnya. Dengan adanya mesin pemipil jagung, maka pekerjaan pemipilan jagung jauh lebih efektif dan efisien dibandingkan secara manual, yaitu dengan menggunakan tangan.

Tongkol jagung yang dapat diolah menjadi pakan ternak adalah tongkol jagung dengan bentuk serpihan.Dengan berbentuk serpihan ini mempermudahkan proses fermentasi yang bertujuan untuk melunakkan tekstur dari tongkol yang telah dihancurkan. Teknik pencacahan menggunakan mata pisau tajam yang berputar pada suatu poros adalah teknik yang tepat untuk menghancurkan tongkol jagung. Dengan teknik seperti ini dapat membantu untuk mengubah bentuk, ukuran serta tekstur dari tongkol jagung yang diolah agar dapat difermentasi dan diproses lebih lanjut (Yuliyana, 2015). Proses pemipilan jagung dari tongkolnya yang terpisah dengan proses penghancuran tongkol jagung sebagai bahan pakan ternak akan membutuhkan waktu proses yang lebih lama, sehingga akan menurunkan efisiensi pekerjaan. Guna mengatasi hal tersebut di atas, maka dirancangbangun mesin yang memadukan dua proses tersebut, sehingga dapat memudahkan proses pengolahan jagung dan tongkolnya dalam satu waktu yang bersamaan. Penelitian ini bertujuan untuk merancangbangun mesin pemipil jagung dan 
penghancur tonggol jagung; dan menguji kinerja mesin pemipil jagung dan penghancur tonggol jagung.

\section{METODE PENELITIAN}

\section{Waktu dan Tempat}

Pembuatan mesin ini dilakukan pada minggu kelima hingga minggu ke dua belas atau tanggal 11 Oktober hingga 29 November 2019 di Laboratorium Logam dan Otomotif, Politeknik Negeri Lampung.

\section{Alat dan Bahan}

Adapun bahan-bahan yang digunakan dapat dilihat pada tabel 1.

Tabel 1. Bahan yang digunakan

\begin{tabular}{|c|c|c|}
\hline NO & Nama Bahan & Jumlah bahan \\
\hline 1 & Baut dan Mur & 24 Buah \\
\hline 2 & Mata Gerinda Potong & 21 Buah \\
\hline 3 & Mata Gerinda Batu & 5 Buah \\
\hline 4 & Amplas & 1,5Meter \\
\hline 5 & Cat Besi & 1 Kaleng \\
\hline 6 & Cairan Tiner & 1 Kaleng \\
\hline 7 & Dempul & 1 Kaleng \\
\hline 8 & Elektroda Las $\emptyset 3,2$ dan 2,6 mm & $7 \mathrm{Kg}$ \\
\hline 9 & PulleyØ3, 4 dan 10 inchi & 3Buah \\
\hline 10 & V-belt B1 62 inchi dan B1 57 inchi & 2 Buah \\
\hline 11 & Motor listrik 3 HP 3 Phase & 1 Buah \\
\hline 12 & Pillow BlockØ 1 Inchi & 4 Buah \\
\hline 13 & Besi Asø $30 \mathrm{~mm}$ & 2 Meter \\
\hline 14 & Besi Plat ketebalan 2 dan $3 \mathrm{~mm}$ & 2 Lembar \\
\hline 15 & Besi Siku $5 \mathrm{~cm}$ x $5 \mathrm{~cm} \times 5 \mathrm{~mm}$ & 4 Batang \\
\hline 16 & Besi Siku $4 \mathrm{~cm}$ x $4 \mathrm{cmx} 3 \mathrm{~mm}$ & 4 Batang \\
\hline 17 & Besi Behel $\varnothing 10 \mathrm{~mm}$ & 2 Buah \\
\hline 18 & Besi Behel $\varnothing 16 \mathrm{~mm}$ & 2,5 Meter \\
\hline 19 & Besi Pipa $\varnothing 85 \mathrm{~mm}$ & $120 \mathrm{~cm}$ \\
\hline 20 & Besi Per Shock Tebal $8 \mathrm{~mm}$ & 1,5 Meter \\
\hline
\end{tabular}

Adapun alat yang digunakan dapat dilihat pada Tabel 2

Tabel 2. Alat yang digunakan

\begin{tabular}{clc}
\hline No & \multicolumn{1}{c}{ Nama alat } & Jumlah \\
\hline 1 & Tang & 3 Buah \\
\hline 2 & Palu & 2 Buah \\
\hline 3 & Roll Meter & 1 Buah \\
\hline 4 & Mistar Siku & 2 Buah \\
\hline 5 & Jangka Sorong & 2 Buah \\
\hline 6 & Kuas & 2 Buah \\
\hline 7 & Las Listrik & 2 Unit \\
\hline 8 & Mesin Bubut & 2 Unit \\
\hline 9 & Gerinda & 2 Unit \\
\hline 10 & Tool Set & 1 Unit \\
\hline 11 & Bor Listrik & 1 Unit \\
\hline 12 & Alat Pelindung Diri & 3 Pasang \\
\hline 13 & Kacamata Pelindung & 3 buah
\end{tabular}




\section{Prosedur Kerja}

Prosedur kerja dalam pembuatan "Rancang Bangun Mesin Pemipil dan Penghancur Tongkol Jagung" ini dapat dilihat dari gambar diagram alir atau flowchart yang disajikan pada Gambar1.

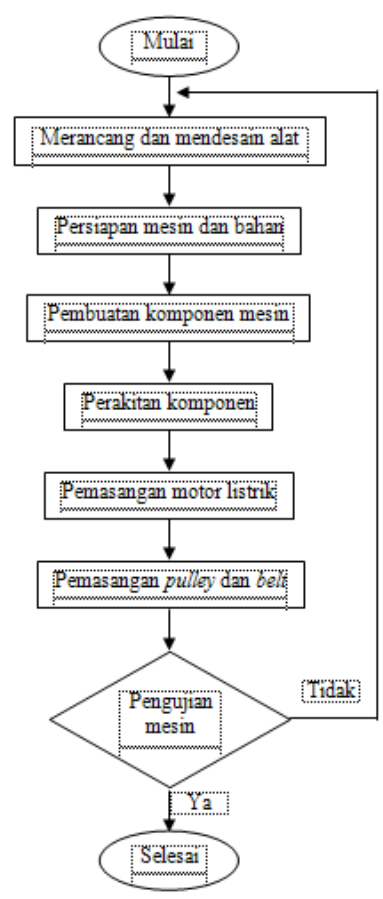

Gambar 1. Diagram alir atau flowchart Prosedur Kerja

\section{Rancangan Mesin}

Rancangan mesin yang berjudul "Rancang Bangun Mesin Pemipil dan Penghancur Tongkol Jagung" terdiri dari dua macam rancangan, rancangan terstruktur dan rancangan fungsional. Gambar rancangan mesin keseluruhan dapat dilihat pada Gambar 2.

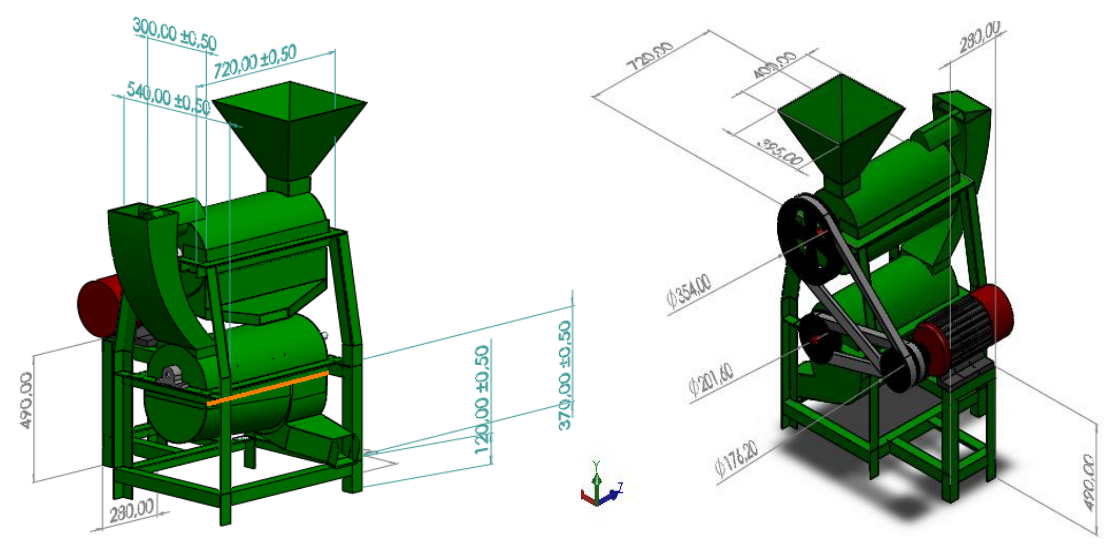

Gambar 2. Rancangan Mesin 
1. Rancangan struktural

Berikut merupakan rancangan struktural pada mesin Pemipil dan Penghancur tongkol jagung ini.

a. Kerangka

Kerangka merupakan bagian yang berada mengelilingi mesin Pemipil dan Penghancur tongkol jagung ini. Kerangka ini menggunakan besi siku ukuran $4 \times 4 \mathrm{~mm}$ dengan ketebalan $3 \mathrm{~mm}$ yang dirakit dengan menggunakan metode las. Berikut ini adalah gambar kerangka yang dapat dilihat pada Gambar 3.

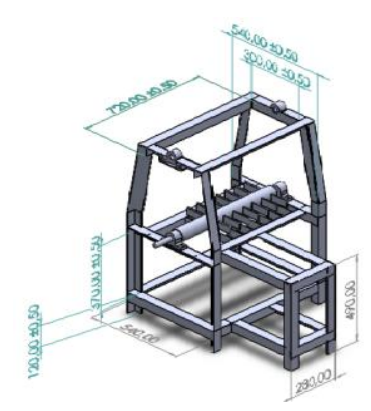

Gambar 3. Kerangka
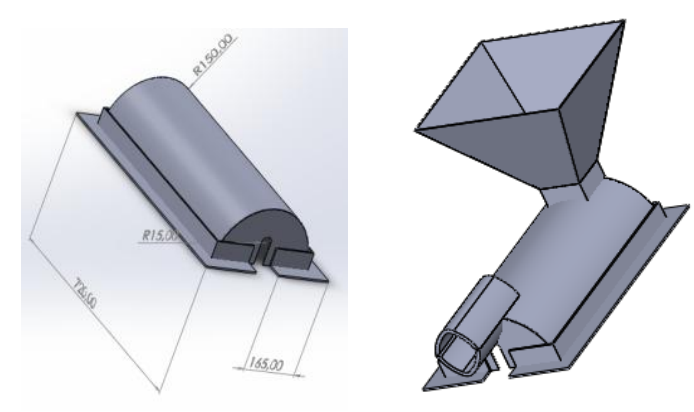

Gambar 4. Cover

b. Cover

Cover menggunakan besi plat ketebalan $3 \mathrm{~mm}$ dan ditempel pada kerangka mesin dengan menggunakan metode las. Gambar Cover dapat dilihat pada Gambar 4.

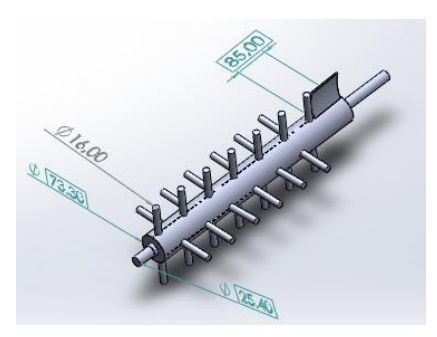

Gambar 5. Poros pemipil

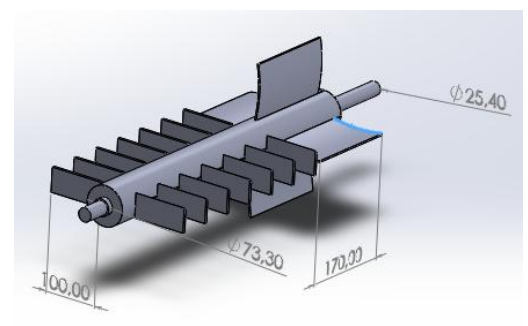

Gambar 6. Poros Penghancur

c. Poros Pemipil

Poros ini merupakan bagian mesin yang berfungsi untuk memipil jagung yang masuk menggunakan hantaman paku paku yang berputar. Poros pendorong yang digunakan berdiameter $73,3 \mathrm{~mm}$ dan as pada poros ini berdiameter 1 inchi, pada ujung poros ini terdapat 2 buah plat berukuran $7 \mathrm{~cm}$ x $5 \mathrm{~cm}$ yang dibuat melengkung agar dapat menerima jagung dengan baik saat jagung masuk melalui hopper, paku paku perontok yang terdapat pada poros perontok ini berjumlah 28 buah masing masing berdiameter 16 $\mathrm{mm}$. Letak poros ini berada didalam cover yang terhubung dengan pulley, poros pemipil 
ini akan diputar melalui hasil transmisi daya dari motor listrik. Gambar poros pemipil dapat dilihat pada Gambar 5.

d. Poros penghancur

Poros ini merupakan bagian dari mesin yang berfungsi menghancurkan tongkol tongkol jagung yang awalnya berbentuk batang menjadi serpihan-serpihan kecil. Poros Penghancur ini terbuat dari besi pipa berdiameter $73 \mathrm{~mm}$, as pada poros ini berdiameter 1 inchi. Poros penghancur ini memiliki 14 buah pisau penghancur yang berfungsi menghancurkan tongkol jagung menjadi serpihan-serpihan kecil serta terdapat 4 buah kipas yang terbuat dari plat berukuran $18 \mathrm{~cm}$ x $10 \mathrm{~cm}$, kipas ini berfungsi untuk menghisap dan menghembuskan serpihan-serpihan tongkol jagung yang terhancurkan agar dapat keluar melalui output letak poros penghancur ini berada di bagian bawah dari ruang pemipil dan berada di dalam ruang penghancur. Gambar poros penghancur dapat dilihat pada Gambar 6.

e. Bantalan

Bantalan yang digunakan berjumlah empat buah bertipe P-206 berdiameter as 1 inchi. Bantalan ini dapat diperoleh dari pasar yang menjual mesin-mesin pertanian, Bantalan ini dipasangkan pada beberapa titik kerangka yang telah ditentukan lalu dihubungkan dengan menggunakan mur dan baut berukuran baut $14 \mathrm{~mm}$ Gambar bantalan dapat dilihat pada Gambar 7.

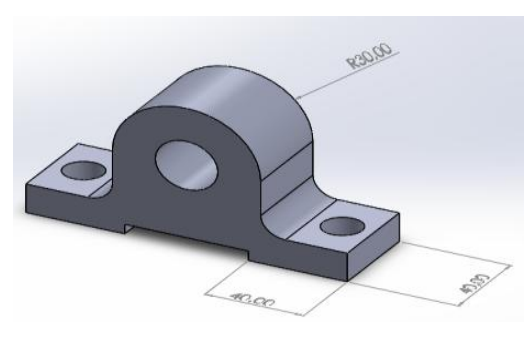

Gambar 7. Bantalan

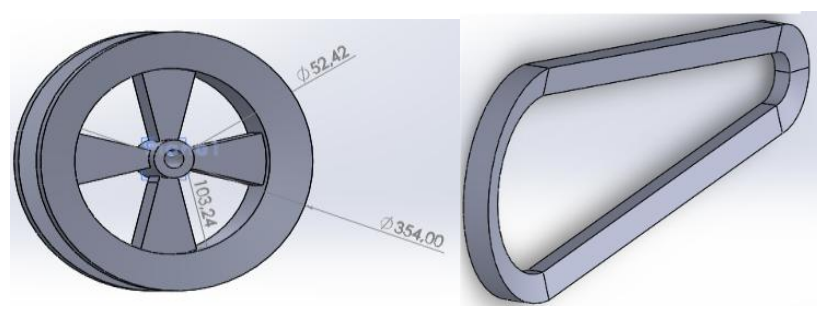

Gambar 8. Pulley dan V-belt

\section{f. PulleydanV-Belt}

Menghubungkan Transmisi daya dari motor listrik ke mesin Pemipil dan Penghancur ini menggunakan pulleydan v-belt. V-belt yang digunakan berjumlah dua buah, sementara pulley yang digunakan berjumlah tiga buah. Pulley pada motor listrik adalah tipe B2 Ø 3 inchi, pulley pada poros pemipil menggunakan pulley bertipe B1 $\varnothing 10$ inchi dan pada poros penghancur menggunakan pulley bertipe B1 $\varnothing 4$ inchi, ini bertujuan agar rpm pada poros pemipil dan penghancur memiliki rpm yang lebih rendah dari rpm motor listrik. $V$ belt dan pulley ini dapat diperoleh dari pasar yang menjual alat-alat pertanian. Adapun gambar v-belt dan pulley dapat dilihat pada Gambar 8. 
g. Motor Listrik

Motor listrik ini memiliki spesifikasi yaitu 3 HP, 3 phase. Berikut ini adalah gambar motor listrik dapat dilihat pada Gambar 9.

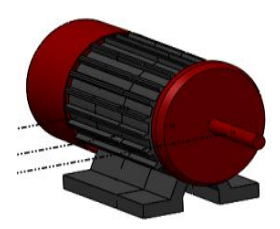

Gambar 9. Motor listrik

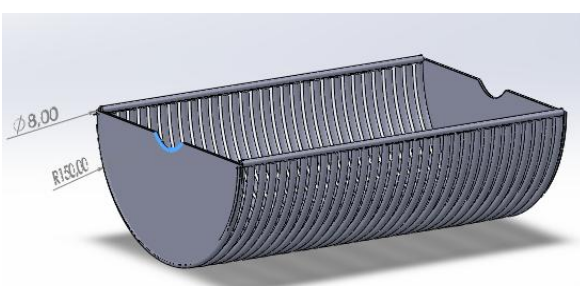

Gambar 10. Mesh

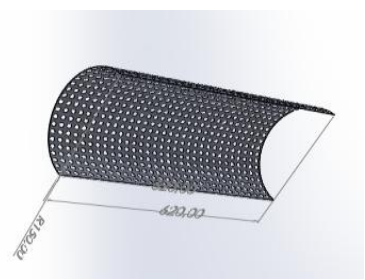

h. Mesh

Mesh yang digunakan pada mesin ini ada 2 yaitu pada ruang pemipil dan penghancur, pada ruang pemipil diameter setiap lubang mesh itu adalah $12 \mathrm{~mm}$, panjang $62 \mathrm{~cm}$ dan lebar setengah lingkaran $30 \mathrm{~cm}$, mesh ini terbuat dari besi plat dengan ketebalan $3 \mathrm{~mm}$. Mesh pada ruang penghacur tetbuat dari besi behel berukuran $\varnothing 10 \mathrm{~mm}$, jarak antar besi behel adalah 1-1,5 cm, panjang mesh ini $40 \mathrm{~cm}$ dan berdiameter setengah lingkaran Ø30 $\mathrm{cm}$, kedua mesh ini terletak pada bagian bawah masing masing ruang pemipilan dan penghancuran tongkol jagung. Berikut ini adalah gambar mesh dapat dilihat pada Gambar 10.

i. Hopper

Mesin ini memiliki 2 hopper yakni hopper pemipilan dan hopper penghancuran, Hopper pemipilan memiliki bentuk kerucut dengan panjang atas $40 \mathrm{~cm}$ lebar atas $39,5 \mathrm{~cm}$, panjang bawah $11 \mathrm{~cm}$, lebar bawah 10,5 cmdan tinggi hopper $29 \mathrm{~cm}$. Hopper penghancuran memiliki bentuk seperti seluncuran, hopper ini memiliki ukuran panjang atas $16 \mathrm{~cm}$, lebar atas $20 \mathrm{~cm}$, tinggi hopper 70-80 $\mathrm{cm}$ dan memiliki lebar bawah sebesar $11 \mathrm{~cm}$ dan panjang $20 \mathrm{~cm}$ ini terletak di bagian atas ruang pemipilan dan penghancuran. Berikut ini adalah gambar Hopper dapat dilihat pada Gambar 11.

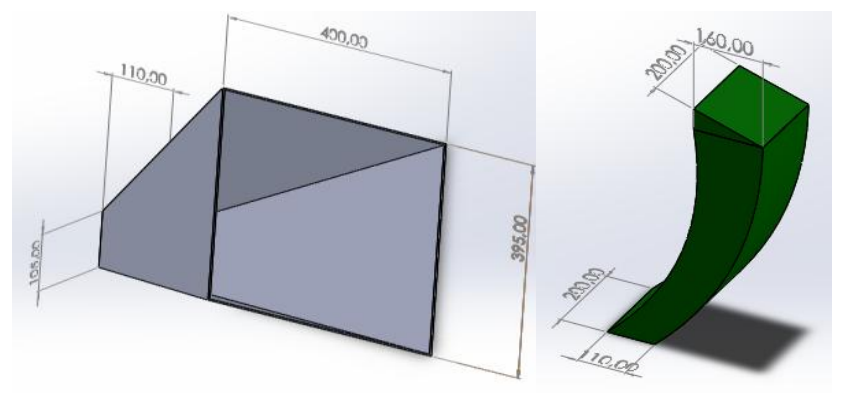

Gambar 11. Hopper 
2. Rancangan Fungsional

Berikut merupakan rancangan fungsional pada mesin pemipil dan penghancur tongkol jagung ini:

a. Kerangka

Kerangka berfungsi untuk tempat peletakan semua komponen-komponen dalam mesin ini, serta menjadi tempat penghubung untuk komponen-komponen yang ada pada mesin ini misalnya motor listrik, bantalan penompang poros dan lain-lain.Gambar kerangka dapat dilihat pada Gambar 3.

b. Cover

Cover atau Penutup mesin dapat digunakan sebagai pelindung adar biji jagung yang terpipil tidak berantakan dan penutup ini juga berfungsi menutupi area yang dapat berpotensi menyebabkan kecelakaan kerja.Gambar cover dapat dilihat pada Gambar 4 .

c. Poros pemipil

Poros pemipil ini brerfungsi untuk merontokkan biji jagung dengan menggunakan gaya hantaman dari paku paku yang berputar pada poros, gaya putar ini dapat menyebabkan benturan antara biji jagung dengan paku yang berada pada poros, benturan dari paku paku tersebut dapat membuat biji-biji tersebut akan terpipil dari tongkolnya.Gambar poros pendorong dapat dilihat pada Gambar 5.

d. Poros Penghancur

Poros Penghancurini berfungsi unuk memperkecil ukuran tongkol jagung menjadi serpihan serpihan dengan cara mencacahnya, poros ini dihubungkan dengan pisau pencacah yang diyakinkan dapat memperkecil ukuran tongkol jagung agar dapat sesuai dengan apa yang diinginkan. Gambar poros penghancur dapat dilihat pada Gambar 6.

e. Bantalan

Bantalan merupakan sebuah mesin yang berfungsi sebagai tempat dudukan untuk poros agar poros dapat berputar dengan baik dan daya dari motor listrik dapat tersalurkan dengan optimal. Gambar bantalan dapat dilihat pada Gambar 7.

f. V-Belt dan Pulley

$V$-Belt dan Pulley Menghubungkan Transmisi daya dari motor listrik ke mesin Pemipil dan Penghancur ini menggunakan $v$-belt dan pulley. Adapun gambar $v$-belt dan pulley dapat dilihat pada Gambar 8.

g. Motor Listrik

Motor listrik ini berfungsi sebagai sumbertenaga atau penggerak untuk menggerakkan poros pemipil dan penghancur. Gambar motor listrik dapat dilihat pada Gambar 9. 
h. Mesh

Mesh ini berfungsi untuk menyeragamkan dan menyaring butiran butiran tongkol jagung yang telah terhancurkan di dalam ruang penghancur dengan ukuran yang diinginkan. Gambar mesh dapat dilihat pada Gambar 10.

i. Hopper

Hopper ini berfungsi sebagai tempat menampung jagung jagung yang akan masuk ke dalam ruang pemipil dan penghancur. Gambar hopper dapat dilihat pada Gambar 11.

3. Prosedur pembuatan mesin

Berikut merupakan prosedur pembuatanmesin pemipil dan penghancur tongkol jagung :

a. menyiapkan alat dan bahan;

b. membuat poros dan komponen pemipil dan penghancur menggunakan mesin bubut dan gerinda;

c. merangkai poros pemipil dan penghancur;

d. membuat kerangka mesin;

e. memasang bantalan pada kerangka mesin dengan dimur dan baut lalu kencangkan;

f. memasang poros di masing-masing tempat yang telah ditentukan;

g. memasukkan as poros perontok pada bantalan, kemudian mengunci pada bantalannya;

h. membuat cover;

i. memasang bagian seluruh cover pada kerangka kemudian dilas;

j. membuat mesh;

k. memasang mesh pada bagian yang telah ditetapkan;

1. membuat output;

m. memasang output pada bagian yang telah ditetapkan;

n. membuat hopper;

o. memasang hopper pada setiap bagian atas ruang penghancur maupun ruang pemipil;

p. memasang motor listrik pada kerangka;

q. memasang seluruh pulley pada tiap as poros perontok dan as motor listrik lalu mengencangkan pada bagian pengunci pulley;

r. memasang V-belt lalu atur posisi pulley dengan menggeser posisi motor listrik; dan

s. mengencangkan motor listrik pada kerangka dengan dimur dan baut.

4. Pengujian dan Evaluasi

Pengujian dan evaluasi dilakukan untuk mengetahui sejauh mana kemampuan mesin untuk merontokkan biji jagung dan menghancurkan tongkol jagung. Pengukuran yang dilakukan berkaitan dengan kapasitas kerja mesin dalam merontokkan jagung serta menghancurkan tongkolnya. 
Berikut ini adalah prosedur kerja pengujian dan evaluasi mesin perontok jagung dan penghancur tongkol jagung:

a. menyiapkan mesin perontok jagung dan bahan jagung yang akan dirontokkan;

b. menimbang berat total bahan yang akan dirontokkan;

c. menghidupkan motor listrik;

d. memasukkan bahan pada hopper;

e. menghitung waktu pemipilan sampai bahan terpisah antara biji jagung dengan tongkolnya;

f. menimbang berat jagung yang terontokkan, tongkol jagung bersih, kotoran, dan jagung yang tidak terpipil;

g. menghitungwaktu penghancuran tongkol jagung saat proses penghancuran;

h. menimbang berat akhir tongkol jagung dan kehilangan hasil pada proses penghacuran;

i. menghitung kapasitas kerja mesin pemipil dan penghancur tongkol jagung.

\section{HASIL DAN PEMBAHASAN}

\section{Mesin Hasil Rancang Bangun}

Mesin pemipil dan penghancur tongkol jagung hasil rancang bangun telah berhasil dibuat dan wujud fisiknya dapat dilihat pada gambar Gambar 12 dan spesifikasinya pada Tabel 3.

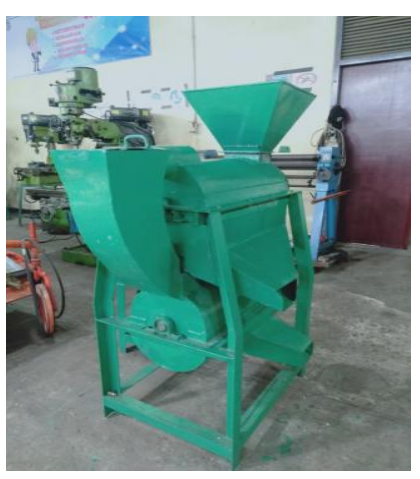

Tampak Isometri

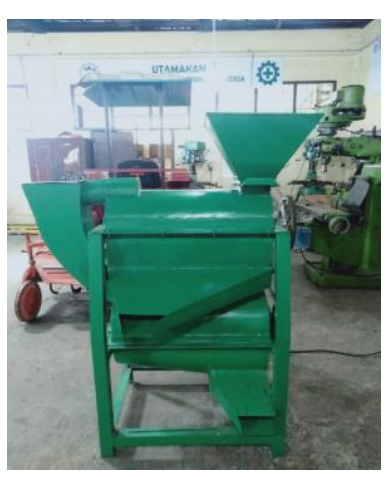

Tampak depan

Gambar 12. Mesin pemipil dan penghancur tongkol jagung

Proses pembuatan dan perakitan mesin ini harus dilakukan secara teliti dan terstruktur dari setiap komponennya. Tahap pertama yaitu membuat kerangka dengan tujuan untuk memudahkan penempatan komponen lainnya. Kemudian membuat poros pemipil dan penghancur dengan menggunakan besi asmasing-masing dengan diameter 73,3 mm sepanjang $80 \mathrm{~cm}$, Selanjutnya pembuatan cover pemipil dan penghancur tongkol jagung, pembuatan 
hopper, perakitan pisau serta kipas pada poros penghancur dan perakitan seluruh komponen seperti cover dan saluran keluaran/output.

Tabel 3. Spesifikasi Mesin

\begin{tabular}{cll}
\hline NO & \multicolumn{1}{c}{ Nama komponen } & \multicolumn{1}{c}{ Spesifikasi komponen } \\
\hline 1 & Tinggi & $120 \mathrm{~cm}$ \\
\hline 2 & Panjang & $72 \mathrm{~cm}$ \\
\hline 3 & Lebar & $54 \mathrm{~cm}$ \\
\hline 4 & Poros Pemipil & $\varnothing 73,3 \mathrm{~mm} \times 80 \mathrm{~cm}$ \\
\hline 5 & Poros Penghancur & $\emptyset 73,3 \mathrm{~mm} \times 80 \mathrm{~cm}$ \\
\hline 6 & Paku Pemipil & $\varnothing 73,3 \mathrm{~mm} \times 8 \mathrm{~cm} \mathrm{x} \mathrm{28} \mathrm{buah}$ \\
\hline 7 & Pisau Penghancur & $8 \mathrm{~mm} \mathrm{x} \mathrm{10} \mathrm{cm} \mathrm{x} \mathrm{28} \mathrm{buah}$ \\
\hline 8 & Pulley Poros Pemipil & B1 Ø10 inchi \\
\hline 9 & Pulley Poros Penghancur & B1 Ø4 inchi \\
\hline 10 & Pulley Motor Listrik & B2 Ø3 inchi \\
\hline 11 & v-belt & B -50 dan B-65 \\
\hline 12 & Kaps. max hopper & $7-7,5 \mathrm{Kg}$ \\
\hline 13 & Kaps. Mesin & 434,0 dan 118,95 kg/jam \\
\hline 14 & Motor Listrik & $3 \mathrm{HP} 3$ Phase \\
\hline & &
\end{tabular}
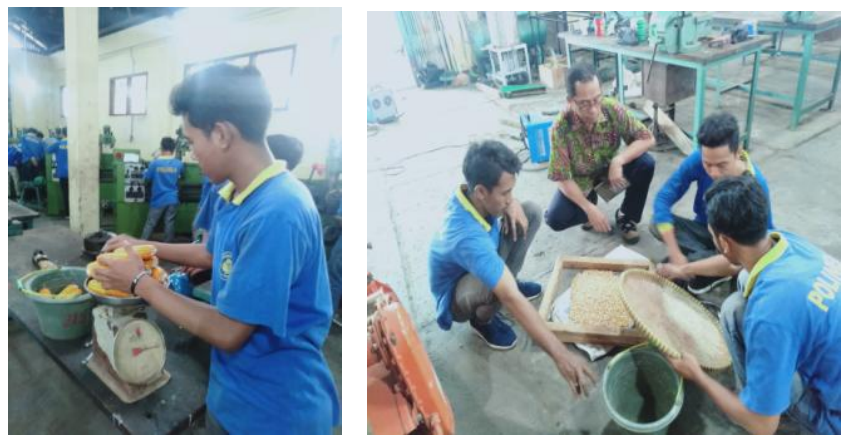

Gambar 13. Pengujian kinerja mesin hasil rancangbangun

Table 4. Data hasil uji mesin pemipil jagung hasil rancang bangun

\begin{tabular}{lcccccccccccc}
\hline Ulangan & $\begin{array}{c}\text { Kadar } \\
\text { Air } \\
\text { Jagung } \\
(\%)\end{array}$ & $\begin{array}{c}\text { Rpm } \\
\text { Tanpa }\end{array}$ & $\begin{array}{c}\text { Reban } \\
\text { dengan } \\
\text { Beban }\end{array}$ & $\begin{array}{c}\text { Berat } \\
\text { jagung } \\
\text { dirontok } \\
(\mathrm{kg})\end{array}$ & $\begin{array}{c}\text { Berat } \\
\text { jagung } \\
\text { yang } \\
\text { rontok } \\
(\mathrm{kg})\end{array}$ & $\begin{array}{c}\text { Berat } \\
\text { jagung } \\
\text { yang tidak } \\
\text { terontok } \\
(\mathrm{kg})\end{array}$ & $\begin{array}{c}\text { Berat } \\
\text { tongkol } \\
\text { jagung } \\
(\mathrm{kg})\end{array}$ & $\begin{array}{c}\text { Berat } \\
\text { kotoran } \\
(\mathrm{kg})\end{array}$ & $\begin{array}{c}\text { Berat } \\
\text { hilang } \\
(\mathrm{kg})\end{array}$ & $\begin{array}{c}\text { Waktu } \\
\text { Total } \\
(\text { detik })\end{array}$ & $\begin{array}{c}\text { Waktu } \\
\text { Total } \\
(\mathrm{menit})\end{array}$ & $\begin{array}{c}\text { Waktu } \\
\text { total } \\
(\text { jama })\end{array}$ \\
\hline 1 & 16,4 & 430 & 369 & 5 & 3,25 & 0,75 & 1,1 & 0,20 & 0,3 & 39,96 & 0,666 & 0,0111 \\
\hline 2 & 17,5 & 428,5 & 375 & 5 & 3,40 & 0,85 & 1 & 0,15 & 0,4 & 41,4 & 0,69 & 0,0115 \\
\hline 3 & 16,9 & 435 & 370 & 5 & 3,31 & 0,35 & 1,15 & 0,17 & 0,2 & 43,2 & 0,72 & 0,0120 \\
\hline Rerata & 16,93 & 431 & 371 & 5 & 3,32 & 0,65 & 1,08 & 0,17 & 0,3 & 41,52 & 0,692 & 0,0115 \\
\hline
\end{tabular}

Pengujian mesin hasil rancang bangun dilakukan menggunakan bahan jagung dengan kadar air 16,4\%-17,5\% (diukur menggunakan moisture tester), rerata putaran poros pemipil 431 rpm, rerata putaran poros penghancur tongkol $826 \mathrm{rpm}$ (diukur menggunakan tachometer). Proses pengujian dapat dilihat pada Gambar 13. 
Hasil pengujian mesin pemipil jagung dan penghancur tongkol jagung dapat dilihat pada table 4 dan tabel 5 .

Tabel 5. Data hasil uji mesin penghancur tongkol jagung hasil rancang bangun

\begin{tabular}{cccccccccc}
\hline Ulangan & $\begin{array}{c}\text { Kadar Air } \\
\text { Tongkol } \\
\text { Jagung }(\%)\end{array}$ & $\begin{array}{c}\text { Rpm } \\
\text { Tanpa } \\
\text { Beban }\end{array}$ & $\begin{array}{c}\text { Rpm } \\
\text { dengan } \\
\text { Beban }\end{array}$ & $\begin{array}{c}\text { Berat tongkol } \\
\text { jagung yang } \\
\text { dihancurkan }(\mathrm{kg})\end{array}$ & $\begin{array}{c}\text { Berat tongkol } \\
\text { jagung yang } \\
\text { terhancurkan } \\
(\mathrm{kg})\end{array}$ & $\begin{array}{c}\text { Berat } \\
\text { kehilangan } \\
(\mathrm{kg})\end{array}$ & $\begin{array}{c}\text { Waktu } \\
\text { Total } \\
\text { (detik) }\end{array}$ & $\begin{array}{c}\text { Waktu } \\
\text { Total } \\
\text { (menit) }\end{array}$ & $\begin{array}{c}\text { Waktu } \\
\text { total } \\
\text { (jama) }\end{array}$ \\
\hline 1 & 18,5 & 815 & 805 & 1,10 & 0,95 & 0,25 & 33,00 & 0,55 & 0,0091 \\
\hline 2 & 21,4 & 840 & 815 & 1 & 0,85 & 0,15 & 31,50 & 0,52 & 0,0087 \\
\hline 3 & 20,3 & 825 & 807 & 1,15 & 0,93 & 0,22 & 34,30 & 0,57 & 0,0095 \\
\hline Rerata & 20,06 & 826 & 809 & 1,08 & 0,91 & 0,20 & 32,93 & 0,54 & 0,0091 \\
\hline
\end{tabular}

Data hasil pengukuran kapasitas produksi mesin pemipil dan penghancur tongkol jagung dapat dilihat pada Table 6 dan Tabel 7.

Tabel 6. Hasil perhitungan rendemen dan kapasitas pemipilan jagung

\begin{tabular}{cccccc}
\hline No & $\begin{array}{c}\text { Berat jagung } \\
(\mathrm{kg})\end{array}$ & $\begin{array}{c}\text { Berat Biji } \\
\text { Jagung }(\mathrm{kg})\end{array}$ & $\begin{array}{c}\text { Waktu pemipilan } \\
(\text { jam })\end{array}$ & $\begin{array}{c}\text { Kapasitas } \\
\text { Pemipilan } \\
(\mathrm{kg} / \mathrm{jam})\end{array}$ & $\begin{array}{c}\text { Rendemen } \\
(\%)\end{array}$ \\
\hline 1 & 5 & 3,25 & 0,0111 & 450,5 & 65 \\
\hline 2 & 5 & 3,40 & 0,0115 & 434,8 & 68 \\
\hline 3 & 5 & 3,31 & 0,0120 & 416,7 & 66,2 \\
\hline & Rerata & & 434 & 66,4 \\
\hline
\end{tabular}

Tabel 7. Hasil perhitungan rendemen dan kapasitas penghancuran tongkol jagung

\begin{tabular}{cccccc}
\hline No & $\begin{array}{c}\text { Berat tongkol } \\
\text { jagung }(\mathrm{kg})\end{array}$ & $\begin{array}{c}\text { Berat tongkol } \\
\text { hancur }(\mathrm{kg})\end{array}$ & $\begin{array}{c}\text { Waktu pemipilan } \\
(\text { jam })\end{array}$ & $\begin{array}{c}\text { Kapasitas } \\
\text { Penghancuran } \\
(\mathrm{kg} / \mathrm{jam})\end{array}$ & $\begin{array}{c}\text { Rendemen } \\
(\%)\end{array}$ \\
\hline 1 & 1,1 & 0,95 & 0,0091 & 104,4 & 86,4 \\
\hline 2 & 1 & 0,85 & 0,0087 & 97,7 & 85 \\
\hline 3 & 1,15 & 0,93 & 0,0095 & 97,9 & 80,9 \\
\hline & Rerata & & 100 & 84,1 \\
\hline
\end{tabular}

Adapun visualisasi hasil pemipilan dan penghancuran tongkol jagung dapat dilihat pada Gambar 14.
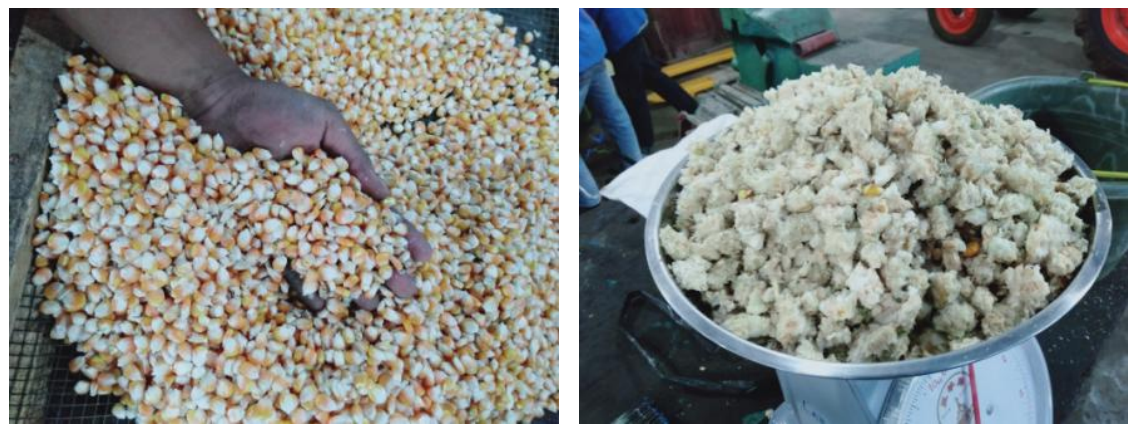

Gambar 14. Hasil pemipilan dan penghancuran tongkol jagung 
Pada Tabel 6 dan 7 menunjukkan bahwa hasil uji performansi mesin hasil rancang bangun mempunyai kapasitas pemipilan sebesar $434 \mathrm{~kg} / \mathrm{jam}$ dengan rendemen 66,4\%, sedangkan mesin penghancur tongkolnya mempunyai kapasitas sebesar $100 \mathrm{~kg} / \mathrm{jam}$ dengan rendemen $84,1 \%$.

\section{KESIMPULAN}

Bedasarkan hasil pemelitian yang telah dilakukan dapat disimpulkan bahwa mesin hasil rancang bangun mempunyai kapasitas pemipilan sebesar $434 \mathrm{~kg} / \mathrm{jam}$ dengan rendemen 66,4\%, sedangkan mesin penghancur tongkolnya mempunyai kapasitas sebesar $100 \mathrm{~kg} / \mathrm{jam}$ dengan rendemen $84,1 \%$.

\section{DAFTAR PUSTAKA}

Adi sarwanto, T.2000. meningkatkan produksi jagung di lahan kering sawah dan pasang surut. PT Penebar Swadaya.Bogor

Dinas Pangan, Pertanian, dan perikanan .2018.mengenal jenis jenis jagung di Indonesia. Pontianak: Kanisius.

Haryoto.1995.Membuat Alat Pemipil Jagung. Yogyakarta: Kanisius.

Koswara, Sutrisno.2009.Teknologi pengolahan Jagung.eBook Pangan.com

S,Agung.2007.Budi Daya Jagung Hibrida. Agromedia Pestisida. Jakarta Selatan

Syukur, M.2013.Jagung manis. penebar swadaya.Jawa Timur 